\title{
Estimating the Size of the Shadow Economy in Nine MENA Countries during the Period 2000 to 2017 Using the MIMIC Model
}

\author{
Ahmed Magdy Abd El Aziz Mansour, Iman Moheb Zaki* \\ Arab Academy for Science and Technology \& Maritime Transport, Alexandria, Egypt \\ Email: ahmedmagdy_914@yahoo.com,imanzaky@aast.edu
}

How to cite this paper: El Aziz Mansour, A.M.A. and Zaki, I.M. (2019) Estimating the Size of the Shadow Economy in Nine MENA Countries during the Period 2000 to 2017 Using the MIMIC Model. Open Access Library Journal, 6: e5508.

https://doi.org/10.4236/oalib.1105508

Received: May 29, 2019

Accepted: July 15, 2019

Published: July 18, 2019

Copyright $\odot 2019$ by author(s) and Open Access Library Inc.

This work is licensed under the Creative Commons Attribution International License (CC BY 4.0). http://creativecommons.org/licenses/by/4.0/

\section{Open Access}

\begin{abstract}
Shadow economy exists in many countries. The unknown shadow economy may interrupt several economic indicators and may result in deviation from the planned and forecasted economic outcomes. The research estimates the size of the shadow economy in Egypt and eight developing MENA countries during the period 2000 to 2017 using the MIMIC approach. The research follows the descriptive explanatory approach based on the quantitative method. The results reveal a significant relation between each of Total Tax/GDP, Intensity of Regulation, and Corruption/Quality of public institutions, Unemployment Rate, Self-employment Rate, and Size of the Agricultural Sector, Fairness of Income Distribution, Entrepreneurial Ecosystem, Labor Force Participation Rate and the Size of the Shadow Economy.
\end{abstract}

\section{Subject Areas}

Managerial Economics, Public Economics

\section{Keywords}

Shadow Economy, GDP, Macro-Economic Indicators, MIMIC Model,

Developing Countries, MENA Countries

\section{Introduction}

Estimating the size of the shadow economy is complicated due to its nature, as indicated in several previous studies including [1]-[6], as the parties who participate and engage in the activities of the shadow economy attempt to remain undetected, however their economic activities should be registered, taxed and add- 
ed to country's GDP [7]. Some researchers observed that the underground activities are increasing rapidly [8], hence the necessity of information regarding the scope of the shadow economy as well as its development over time is important due to its political and economic effects. Total economic activities, including both official and unofficial production of goods and services are foreseen primary in designing economic policies that should be coping with the degree of economic development over time. In addition, estimating the size of the shadow economy is essential in order to evaluate the range of tax evasion, as well as evaluating corruptive actions domination and provide tools of control.

The shadow economy includes three main types of activities being: non-market economic activities (household economic production), illegal and prohibited activities and legal market activities which are not observed and unregistered due to reasons of tax-evasion. Whereas, the legal market activities are considered to be the most important to economists [9]. In this concern, this study follows Schneider's definition for the shadow economy being; the shadow economy includes all economic activities that are not detected by the official authorities due to several reasons either regulatory or monetary or institutional.

\section{Literature Review}

The shadow economy is a global issue and it is also known as; unofficial economy, informal economy, grey economy, hidden economy, parallel economy, underground economy, cash economy or the black economy, [10]. The presence of the shadow economy is obviously found in almost all countries regardless of its stage of economic development and political regime, whereby the shadow economy is a clear fact that exists along with the official economy and tangible relation between them is revealed [11].

The shadow economy comprises all the economic activities that are intentionally hidden from the official economy and governmental authorities for several reasons; these reasons may be monetary reasons as: tax evasion and trying not to pay taxes and/or social security contributions, or regulatory reasons as: routine and governmental bureaucracy or regulatory framework's burden and institutional reasons as: corruption, misfit political institutions and inefficient governmental laws and regulations [12].

The official economy, as well as the social life in any country, is affected and influenced by the presence of the shadow economy, whereby the shadow economy leads to disrupting the labor market and results in misleading indicators such as; the unemployment rate and the labor force, and that may result in wrong governmental decisions in the form of increasing the tax base (Hassan and Schneider, 2016). It was revealed from some empirical studies that a reduction in the official economy may be accompanied with a rise in the shadow economy and vice versa [11].

Accordingly, it is argued that safeguarding the official economy could be achieved by penalizing the shadow economy; hence countries exert efforts to enhance their official economy via preserving the development of the shadow 
economy [13]. Nevertheless, it is not necessarily to deal with the shadow economy as an enemy that threatens the official economy, as the official economy is stimulated by the income gained by individuals participating in the shadow economy after being later injected in the official economy, whereby two thirds of the generated income from activities within the shadow economy is later disbursed in the formal economy [6] [14].

\section{Defining the Shadow Economy}

The shadow economy is considered as an undetectable economic phenomenon and its definition is far from completion [1] [6] [10] [15]-[33]. One of the spacious definitions includes "those economic activities and the income derived from them that bypass government regulation, taxation or observation" [34] [35] [36] [37] [38]. Another broad definition according to is; "the unofficial sector that covers economic activities which are generally not recorded in the national economic activities". It was viewed that; the economic outputs generated from unregistered activities are included in the shadow economy [39].

In this concern, this study pursues Schneider's particular definition of the shadow economy being; the shadow economy considers the legitimate economic activities that, if registered, should contribute to the country's GDP. In this aspect, the shadow economy comprises all market-based, lawful production or trade of goods and services intentionally concealed from governmental authorities so that to; avoid either payment of income, or taxes, or social security dues, or to get around some labor market conditions, such as; minimum salaries, labor rights, safety standards, maximum working hours; or to evade from being in compliance with administrative procedures [14]. In addition, this study does not take into consideration illegitimate or criminal activities, charitable, do-it-yourself, or household activities.

\section{Estimating the Size of the Shadow Economy Using the MIMIC Model Approach}

Examining the shadow economy and estimating its size is a complicated and challenging task [40] [41] [42] [43] and [44]. The MIMIC model approach explicitly considers multiple causes and indicators of the existence of the shadow economy, as well as its multiple effects over time [5] [25] [26] [35] [45] [46]. This empirical method differs from other approaches that were previously applied so far, as the MIMIC Model depends on the statistical theory of the unobserved variables, hence considering multiple causes and indicators of the shadow economy.

Due to the hidden nature of the size of the shadow economy and being unknown, the MIMIC Model is applied using a latent estimator approach. The statistical idea for the MIMIC model is to set a comparison between a sample covariance matrix, being a covariance matrix of observable variables and the parametric structure imposed on this matrix using a hypothesized model. First, the 
unobservable variable is linked to observable variables in a factor analytical model, which is also called a measurement model. This linkage takes place using covariance information among the observable variables. Afterwards, the structural model enables to specify relationships between the unobservable and observable variables. Hence, a MIMIC model is foreseen as a simultaneous specification of a factor and a structural model. In this matter, the MIMIC model examines the uniformity of a structural theory via data. Accordingly, the MIMIC approach is being a confirmatory technique rather than an exploratory one.

Consequently, an economic theory is being tested checking the uniformity of the actual data with the hypothesized relationships between the variables being the unobservable (latent) variable as well as the observable (measurable) variables. In this concern, a confirmatory factor analysis tries to estimate parameters like coefficients and variances; in addition, it looks forward to assessing if the model is being convenient or not. The concept of the MIMIC model is based on examining the relationships between the shadow economy "latent variable" and observable variables in terms of the relationships between a set of observable variables by using their data of covariance. The observable variables are classified into causes and indicators of the latent variable.

\subsection{The Causal Variables}

Eight major causal variables for the shadow economy are briefly addressed including; tax burden, intensity of regulations, corruption, unemployment rate, self-employment rate, size of the agriculture sector, fairness of income distribution and entrepreneurial eco system.

\section{Tax and Social Security Contribution Burden}

The shadow economy is positively affected by higher taxes, as a significant and positive relationship is observed. In the MIMIC model applied in this study, tax burden is measured by total tax revenues as percentage of GDP [5] [7] [17] [25] [28] [47] and [48].

Hypothesis 1: The higher the tax burden, the larger the size of the shadow economy, ceteris paribus.

\section{Intensity of regulation}

Each measure of regulation is directly correlated with the size of the shadow economy and the more rules and regulations result in increasing the size of the shadow economy. In addition, the regulatory burden leads to larger sizes of shadow economy. The MIMIC model applied in this study follows the measure of regulatory burden applied in [12], whereby regulatory burden is measured by total government spending as percentage of GDP [12] [26] [27] [28] [49].

Hypothesis 2: The more intensive the regulatory burden, the larger the size of the shadow economy, ceteris paribus.

Corruption/the quality of public institutions

The relationship between corruption and shadow economy can be viewed either as a complementary (positive) or substitutional (negative) relationship. In 
the MIMIC model applied in this study, level of corruption is measured by the corruption perception index (CPI) [1] [12] [28] [32] [50] [51] [52] [53].

Hypothesis 3: The higher the level of corruption, the larger the size of the shadow economy, ceteris paribus.

Unemployment

A positive relationship between the unemployment and the shadow economy is revealed. However, a negative relationship was revealed during recession. In the MIMIC model applied in this study, unemployment is measured by the total unemployment as a percentage of labor force.

Hypothesis 4: The higher the unemployment rate, the larger the size of the shadow economy, ceteris paribus.

\section{Self-employment}

It is observed that self-employment has a positive and significant effect on the size of the shadow economy. In the MIMIC model applied in this study, self-employment is measured by the total self-employed as percentage of total employed.

Hypothesis 5: The higher the self-employment rate, the larger the size of the shadow economy, ceteris paribus.

Size of the agricultural sector

A positive relationship between the level of the agricultural sector and the shadow economy is found. In the MIMIC model applied in this study, size of the agriculture sector is measured by the agricultural value-added as $\%$ of GDP.

Hypothesis 6: The more dominant the agriculture sector, the larger the size of the shadow economy, ceteris paribus.

Income inequality

It is observed that the relationship between income inequality and the shadow economy is positive. In the MIMIC model applied in this study, income inequality is measured by the Gini coefficient (Gini).

Hypothesis 7: The less the level of income equality, the larger the size of the shadow economy, ceteris paribus.

Entrepreneurship

An argument was found regarding the relationship between entrepreneurship and economic development. In the MIMIC model applied in this study, entrepreneurship is measured by the Cost of starting a business.

Hypothesis 8: The more intensity of regulation, the high corruption, higher unemployment, higher self-employment rate and higher income inequality will negatively affect productive entrepreneurship and consequently the larger the size of the shadow economy, ceteris paribus.

\subsection{Indicators of the Shadow Economy "Dependent Variables"}

Four major indicators of the shadow economy are briefly addressed including; Real GDP growth rate "Formal economy", Currency/cash outside banks, Labor force participation rate and Inflation.

Real GDP Growth Rate (economic growth) 
The relationship between the official economy (GDP) and the shadow economy differs from one country to another, as no consensus exists in the literature about the exact type of the relationship between the two variables. In the MIMIC model applied in this study, the real GDP index is used as an indicator to reflect the existence of the shadow economy.

Hypothesis 9: The larger the size of the shadow economy, the lower the GDP growth rate, ceteris paribus.

Currency/cash outside banks

A significant and positive relationship was observed between the size of the shadow economy and currency held by the public. In the MIMIC model applied in this study, currency is proxied by the ratio of M1 over M2.

Hypothesis 10: The larger the size of the shadow economy, the larger the money held and transacted by the public, ceteris paribus.

Labor force participation rate

The effect of the participation rate of registered labor on the shadow economy is subject to an argument. In the MIMIC model applied in this study, labor force participation rate is measured by the total of workforce as percentage of working age population.

Hypothesis 11: The larger the size of the shadow economy, the lower the official labor force participation rate, ceteris paribus.

\section{Inflation}

A significant and positive relationship was observed between the size of the shadow economy and inflation. In the MIMIC model applied in this study, the inflation is measured by the GDP Deflator.

Hypothesis 12: The larger the size of the shadow economy, the larger the inflation rate, ceteris paribus

\section{Empirical Study}

Applying the MIMIC approach to estimate the size of the shadow economy for nine developing countries including Egypt in the period from 2000 to 2017. The estimation is done using SEM analysis. Accordingly, the descriptive analysis is presented for the research variables, representing the causes and indicators of the shadow economy.

To assess the determinants of the size of the shadow economy, correlation and regression analyses are used to test the hypotheses for the current research. In addition, the regression assumptions are verified to be able to rely on the results obtained from the analysis. Finally, the conclusion section represents a summary of the main findings of the current research. The following section uses the SEM analysis to estimate the size of the shadow economy using the MIMIC approach.

\subsection{Estimating the Size of the Shadow Economy Using the MIMIC Approach Applying the Structural Equation Modeling}

The MIMIC model is a structural equation modeling (SEM), being a confirmatory method that emphasizes the influence of a group of causal variables on the 
latent variable (shadow economy), accompanied by the influence of the shadow economy on macroeconomic indicators, a structural equation model can be expressed as:

$$
\eta=\gamma^{\prime X}+\zeta
$$

where: $X=\left(x_{1}, x_{2}, \cdots, x_{q}\right)$ is a $(q \times 1)$ vector and each $x_{i}, i=1, \cdots, q$ is a potential cause of the latent variable and $y_{u}=\left(y_{1}, y_{2}, \cdots, y_{q}\right)$ is a $(1 \times q)$ vector of coefficients describing the relationships between the latent variable and its causes. As such, the latent variable $\eta$ is determined by a set of exogenous causes and $\zeta$ represent the error term.

A measurement model can be expressed as:

$$
y=\lambda \eta+\varepsilon
$$

where $y=\left(y_{1}, y_{2}, \cdots, y_{p}\right)$ is a $(p \times 1)$ vector of several indicator variables. $\lambda$ is the vector of regression coefficients, and $\varepsilon^{\prime}$ is a $(p \times 1)$ vector of white noise disturbances. When Equations (2) and (3) are combined, a multivariate regression model is formed in which endogenous variables $y_{j}, j=1, \cdots, p$ are indicator variables of a shadow economy variable 5 and exogenous variables $x_{i}, i=1, \cdots, q$ are cause variables of a shadow economy variable 5 . A general equation can be expressed as below:

From (3) $\eta=\lambda^{-1}(y-\varepsilon)$,

From (2) and (3):

$$
\begin{gathered}
\gamma^{\prime X}+\zeta=\lambda^{-1}(y-\varepsilon) \\
y=\lambda \gamma^{\prime X}+\lambda \zeta+\varepsilon \\
\gamma=\Pi X+z
\end{gathered}
$$

In this section, the MIMIC approach is implemented to estimate the size of the shadow economy using the SEM analysis. Figure 1 shows the proposed SEM model for the research model, where the research variables are: Total Tax/GDP, Intensity of Regulation, Corruption/Quality of public institutions, Unemployment Rate, Self-employment Rate, and Size of the Agricultural Sector, Fairness of Income Distribution and Entrepreneurial Ecosystem represent the causes of the size of the shadow economy. Also, the research variables; Real GDP Growth Rate, Coins and Currency in Circulation, Labor Force Participation Rate and Inflation represent the indicators of the size of the shadow economy.

The proposed model shown in Figure 1 faces several problems regarding the model fit indices of the model which requires deleting some variables to reach the optimum model with the best fit indices for the model.

Accordingly, the model actually applied includes the research variables; Intensity of Regulation, Corruption/Quality of public institutions, Fairness of Income Distribution and Entrepreneurial Ecosystem representing the causes of the size of the shadow economy and Real GDP Growth Rate, Coins and Currency in Circulation and Labor Force Participation Rate representing the indicators of the 


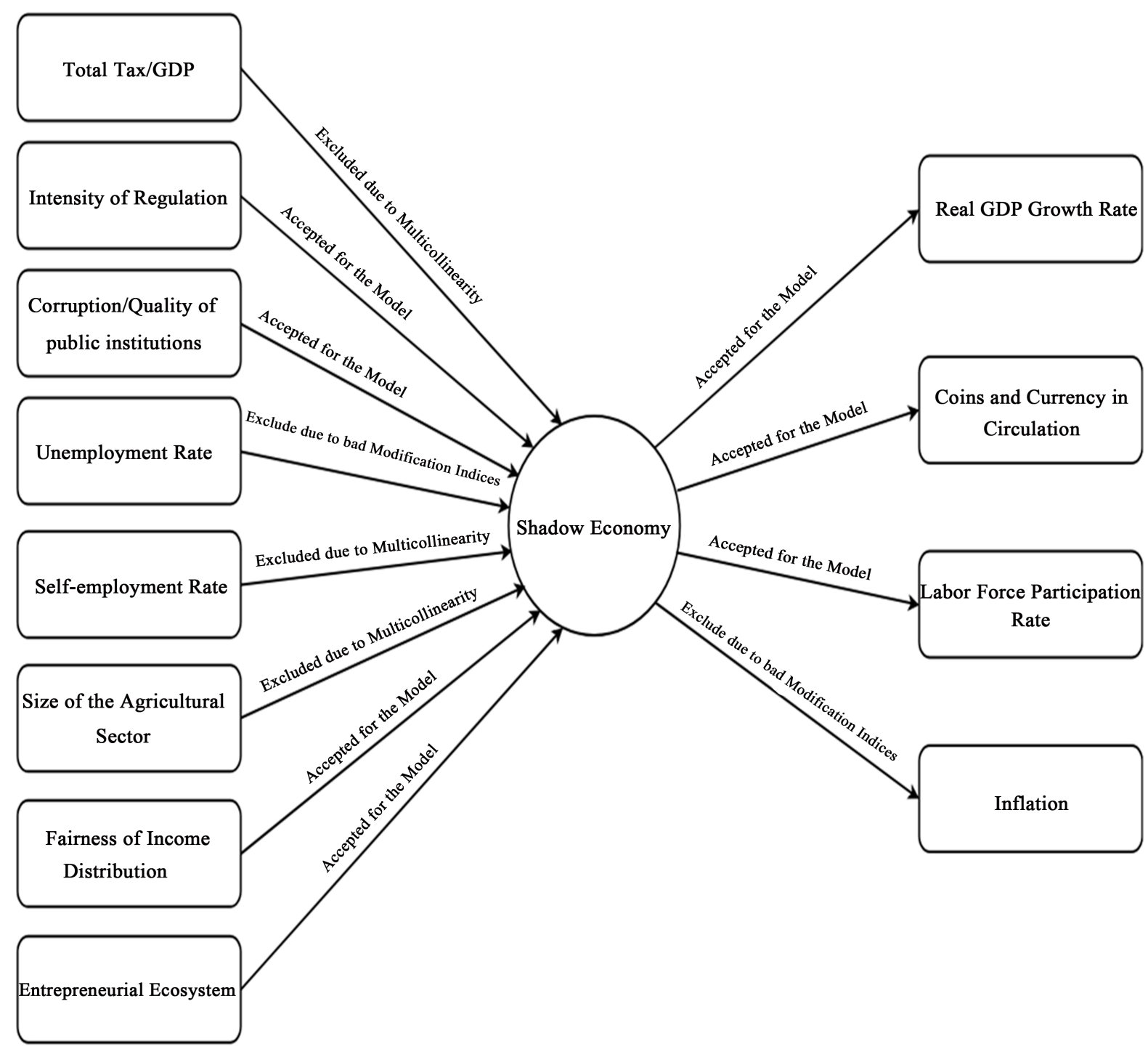

Figure 1. Proposed SEM for the research model.

size of the shadow economy. Other variables were deleted due to multicollinearity problem and bad modification indices, which is discussed below in details.

Figure 2 shows the model fitted after deleting variables leading to the problem of multicollinearity. The fit indices shown for the model were as follows; $\mathrm{CMIN} / \mathrm{DF}=2.717, \mathrm{GFI}=0.964, \mathrm{CFI}=0.853, \mathrm{AGFI}=0.873$, and $\mathrm{RMSEA}=0.103$ all are within their acceptable levels, which makes the model acceptable as shown in Figure 2.

Regarding testing the MIMIC approach, Table 1 shows the SEM analysis of the impact of Research Variables; Intensity of Regulation, Corruption Quality of public institutions, Fairness of Income Distribution and Entrepreneurial Ecosystem on Shadow Economy. It could be observed that there is a positive significant impact of Intensity of Regulation and Entrepreneurial Ecosystem on Shadow Economy, as the estimates are 0.103, and 0.068, as well as p-value is less than 0.05 . 


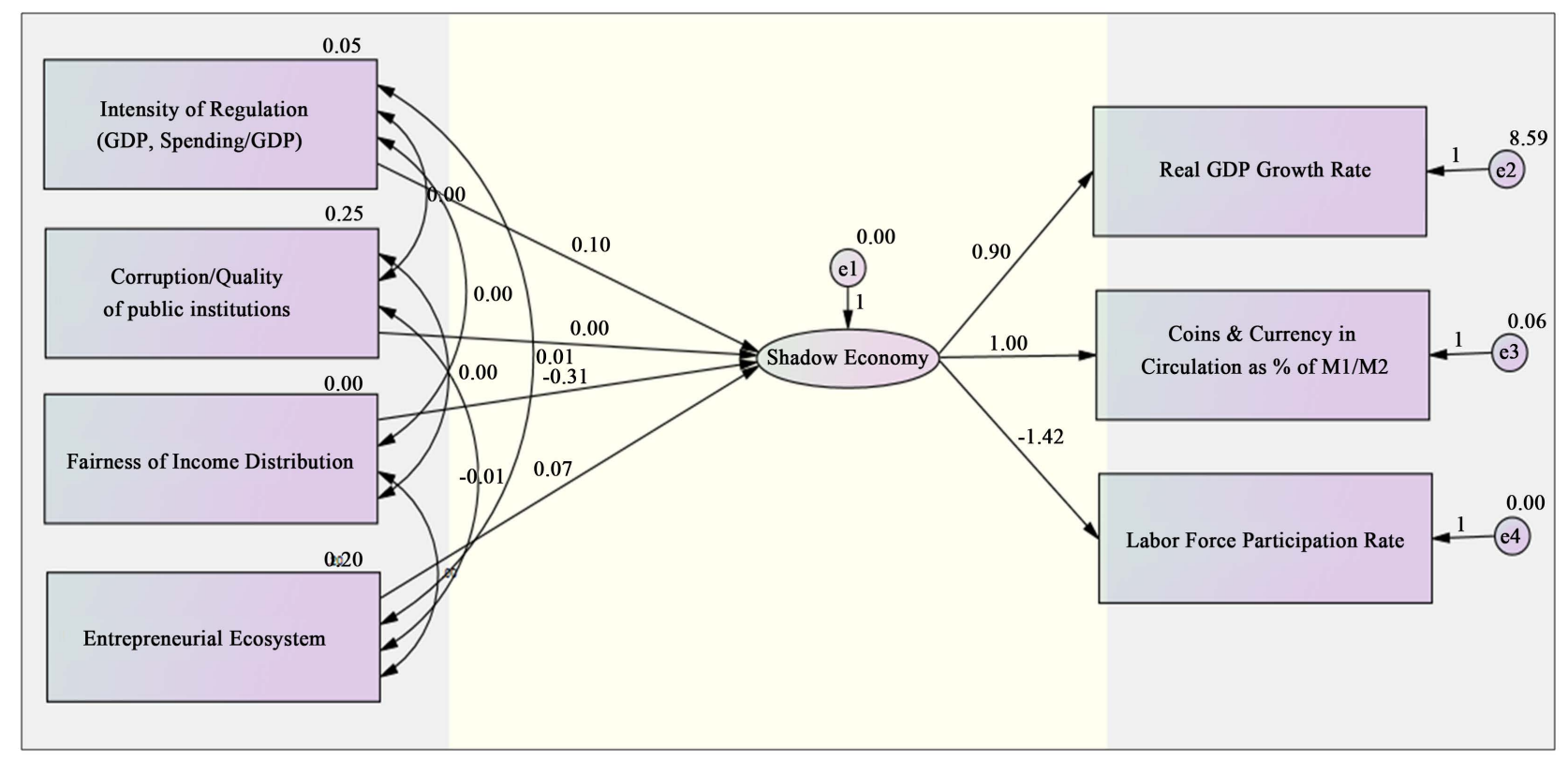

Figure 2. Actual SEM applied for the research model.

Table 1. SEM analysis of research model.

\begin{tabular}{lcccc}
\hline & & & Estimate & $\mathrm{P}$ \\
\hline Shadow Economy & $\leftarrow$ & Intensity of Regulation & 0.103 & 0.035 \\
Shadow Economy & $\leftarrow$ & Corruption Quality of public institutions & 0.001 & 0.920 \\
Shadow Economy & $\leftarrow$ & Fairness of Income Distribution & -0.312 & 0.143 \\
Shadow Economy & $\leftarrow$ & Entrepreneurial Ecosystem & 0.068 & 0.030 \\
\hline
\end{tabular}

\subsection{Testing Research Hypotheses}

In this section, the hypotheses under study are tested using the correlation and regression. The hypotheses are tested in two steps. The first step is testing the relationship between size of shadow economy and its causes, which are; Total Tax/GDP, Intensity of Regulation (Government Spending/GDP), Corruption/Quality of public institutions, Unemployment Rate, Self-employment Rate, Size of the Agricultural Sector, Fairness of Income Distribution, and Entrepreneurial Ecosystem. The second step is testing the relation between sizes of shadow economy and its indicators, which are; Real GDP Growth Rate, Coins and Currency in Circulation, Labor Force Participation Rate and Inflation. The two steps are presented in the following two subsections.

Testing the Relationship between Size of Shadow Economy and Its Causes

This section investigates the relationship between Research Variables and Size of Shadow Economy. As the formal and informal tests show that data under study are not normally distributed, Spearman correlation coefficient is used. Table 2 shows the correlation matrix for the relationship between Total Tax/GDP, Intensity of Regulation (Government Spending/GDP), Corruption/Quality of public institutions, Unemployment Rate, Self-employment Rate, and Size of the 
Table 2. Correlation matrix between research variables and size of shadow economy.

\begin{tabular}{|c|c|c|c|c|c|c|c|c|c|c|}
\hline & & 1 & 2 & 3 & 4 & 5 & 6 & 7 & 8 & 9 \\
\hline \multirow{3}{*}{ 1) Total Tax/GDP } & $\begin{array}{l}\text { Spearman's } \\
\text { rho Correlation }\end{array}$ & 1.000 & & & & & & & & \\
\hline & Sig. (2-tailed) & & & & & & & & & \\
\hline & $\mathrm{N}$ & 84 & & & & & & & & \\
\hline \multirow{3}{*}{ 2) Intensity of Regulation } & $\begin{array}{l}\text { Spearman's } \\
\text { rho Correlation }\end{array}$ & 0.085 & 1.000 & & & & & & & \\
\hline & Sig. (2-tailed) & 0.439 & & & & & & & & \\
\hline & $\mathrm{N}$ & 84 & 162 & & & & & & & \\
\hline \multirow{3}{*}{$\begin{array}{l}\text { 3) Corruption/Quality } \\
\text { of public institutions }\end{array}$} & $\begin{array}{l}\text { Spearman's } \\
\text { rho Correlation }\end{array}$ & $-0.604^{\star \star}$ & 0.008 & 1.000 & & & & & & \\
\hline & Sig. (2-tailed) & 0.000 & 0.921 & & & & & & & \\
\hline & $\mathrm{N}$ & 84 & 162 & 162 & & & & & & \\
\hline \multirow{3}{*}{ 4) Unemployment Rate } & $\begin{array}{l}\text { Spearman's } \\
\text { rho Correlation }\end{array}$ & $0.734^{* *}$ & $0.170^{*}$ & $-0.361^{\star *}$ & 1.000 & & & & & \\
\hline & Sig. (2-tailed) & 0.000 & 0.030 & 0.000 & & & & & & \\
\hline & $\mathrm{N}$ & 84 & 162 & 162 & 162 & & & & & \\
\hline \multirow{3}{*}{ 5) Self-employment Rate } & $\begin{array}{l}\text { Spearman's } \\
\text { rho Correlation }\end{array}$ & $0.735^{\star *}$ & 0.035 & $-0.481^{\star *}$ & $0.712^{* *}$ & 1.000 & & & & \\
\hline & Sig. (2-tailed) & 0.000 & 0.654 & 0.000 & 0.000 & & & & & \\
\hline & $\mathrm{N}$ & 84 & 162 & 162 & 162 & 162 & & & & \\
\hline \multirow{3}{*}{$\begin{array}{l}\text { 6) Size of the } \\
\text { Agricultural Sector }\end{array}$} & $\begin{array}{l}\text { Spearman's } \\
\text { rho Correlation }\end{array}$ & $0.690^{* *}$ & 0.007 & $-0.628^{\star *}$ & $0.689^{* *}$ & $0.889^{* *}$ & 1.000 & & & \\
\hline & Sig. (2-tailed) & 0.000 & 0.935 & 0.000 & 0.000 & 0.000 & & & & \\
\hline & $\mathrm{N}$ & 84 & 162 & 162 & 162 & 162 & 162 & & & \\
\hline \multirow{3}{*}{$\begin{array}{l}\text { 7) Fairness of Income } \\
\text { Distribution }\end{array}$} & $\begin{array}{l}\text { Spearman's } \\
\text { rho Correlation }\end{array}$ & 0.181 & -0.101 & 0.228 & -0.301 & 0.105 & -0.219 & 1.000 & & \\
\hline & Sig. (2-tailed) & 0.446 & 0.589 & 0.218 & 0.100 & 0.572 & 0.237 & & & \\
\hline & $\mathrm{N}$ & 20 & 31 & 31 & 31 & 31 & 31 & 31 & & \\
\hline \multirow{3}{*}{$\begin{array}{l}\text { 8) Entrepreneurial } \\
\text { Ecosystem }\end{array}$} & $\begin{array}{l}\text { Spearman's } \\
\text { rho Correlation }\end{array}$ & $0.336^{* *}$ & -0.105 & $-0.335^{\star *}$ & $0.656^{\star *}$ & $0.414^{* *}$ & $0.508^{\star *}$ & -0.177 & 1.000 & \\
\hline & Sig. (2-tailed) & 0.005 & 0.233 & 0.000 & 0.000 & 0.000 & 0.000 & 0.367 & & \\
\hline & $\mathrm{N}$ & 69 & 131 & 131 & 131 & 131 & 131 & 28 & 131 & \\
\hline \multirow{3}{*}{$\begin{array}{l}\text { 9) Size of Shadow } \\
\text { Economy }\end{array}$} & $\begin{array}{l}\text { Spearman's } \\
\text { rho Correlation }\end{array}$ & $0.490^{* *}$ & $0.317^{\star \star}$ & $-0.411^{\star *}$ & $0.686^{\star *}$ & $0.483^{\star \star}$ & $0.573^{* *}$ & -0.099 & $0.828^{* *}$ & 1.000 \\
\hline & Sig. (2-tailed) & 0.000 & 0.000 & 0.000 & 0.000 & 0.000 & 0.000 & 0.618 & 0.000 & \\
\hline & $\mathrm{N}$ & 69 & 128 & 128 & 128 & 128 & 128 & 28 & 128 & 128 \\
\hline
\end{tabular}

Source: Author's calculations. 
Agricultural Sector, Fairness of Income Distribution, Entrepreneurial Ecosystem and Size of Shadow Economy.

It is found that there is a significant positive relation between Total Tax/GDP, Intensity of Regulation (Government Spending/GDP), Unemployment Rate, Self-employment Rate, Size of the Agricultural Sector, Entrepreneurial Ecosystem and Size of Shadow Economy as the corresponding P-values are less than 0.05 and correlation coefficients are $0.490,0.317,0.686,0.483,0.573$, and 0.828 respectively. On the other hand, there is a significant negative relation between Corruption/Quality of public institutions and Size of Shadow Economy as the corresponding P-value is less than 0.05 and correlation coefficient is -0.411 . Moreover, there is an insignificant relation between Fairness of Income Distribution and Size of Shadow Economy as the corresponding P-value is more than 0.05 .

The results obtained by the MIMIC approach leads to the estimation of the size of the shadow economy as shown in Table 3. Table 3 shows the descriptive analysis of the Index of Shadow Economy as a percentage of GDP. It could be observed that the highest average size of the shadow economy for the period 2000 to 2017 was in Jordan with $23.8 \%$, while the lowest average size of the shadow economy for the period 2000 to 2017 was in Bahrain with 11.15\%. Regarding Egypt, the average size of the shadow economy for the period 2000 to 2017

Table 3. Index of shadow economy as a percentage of GDP using the MIMIC approach ${ }^{1}$.

\begin{tabular}{|c|c|c|c|c|c|c|c|c|c|}
\hline & sypt & Algeria & Morocco & UAE & Bahrain & Oman & $\mathrm{KSA}$ & Jordan & Turkey \\
\hline 2000 & & & & & & & & & \\
\hline & & & & & & & & & \\
\hline & & & & & & & & & \\
\hline & $24.27 \%$ & $20.30 \%$ & $22.47 \%$ & $18.85 \%$ & & $18.57 \%$ & $26.88 \%$ & $27.78 \%$ & $22.02 \%$ \\
\hline & $24.06 \%$ & $19.65 \%$ & $20.64 \%$ & $18.15 \%$ & $11.15 \%$ & & & $27.34 \%$ & $20.90 \%$ \\
\hline 2005 & & & & $17.38 \%$ & $11.15 \%$ & $18.21 \%$ & $26.32 \%$ & $26.43 \%$ & $21.14 \%$ \\
\hline 2006 & & & & & & & & & \\
\hline & & $18.60 \%$ & & & & & & & \\
\hline 2008 & & & & & & $15.64 \%$ & & & $19.82 \%$ \\
\hline 2009 & & $19.81 \%$ & & $17.51 \%$ & & $15.58 \%$ & $19.97 \%$ & $23.66 \%$ & $20.30 \%$ \\
\hline 2010 & $20.04 \%$ & $20.28 \%$ & $19.80 \%$ & $17.80 \%$ & $9.94 \%$ & $16.49 \%$ & $20.30 \%$ & $23.07 \%$ & $20.61 \%$ \\
\hline 2011 & $20.27 \%$ & $20.91 \%$ & $19.90 \%$ & $17.94 \%$ & $11.45 \%$ & $16.28 \%$ & $19.68 \%$ & & $20.26 \%$ \\
\hline & & & & $17.26 \%$ & & & & & \\
\hline & & & & & & & & & \\
\hline & & & & & & & & & \\
\hline & & & & & & & & & $20.92 \%$ \\
\hline 2016 & & $20.68 \%$ & & & & $17.08 \%$ & $19.84 \%$ & $22.32 \%$ & $21.17 \%$ \\
\hline 2017 & $19.10 \%$ & $20.21 \%$ & $19.39 \%$ & $18.90 \%$ & $11.15 \%$ & $17.08 \%$ & $20.04 \%$ & $22.78 \%$ & $20.13 \%$ \\
\hline Average & $21.43 \%$ & $19.90 \%$ & $20.19 \%$ & $17.70 \%$ & $11.15 \%$ & $17.08 \%$ & $21.97 \%$ & $23.81 \%$ & $20.75 \%$ \\
\hline
\end{tabular}

Source: Author's calculations.

${ }^{1}$ According to the data gathered from World Development Indicators (2019), the selection is based on the convergence of the Average GDP Growth Rate for the selected countries; Algeria, Morocco, United Arab Emirates, Bahrain, Oman, Saudi Arabia, Jordan, and Turkey with respect to the average GDP growth of Egypt during the period 2000 to 2017, in addition to being developing countries and located in the MENA region. 
was $21.4 \%$, which means that Egypt is closer to the highest index of the shadow economy in the developing countries. This means that a focus on policies dealing with such a relatively huge shadow economy has to be applied to minimize its size.

Figure 3 shows a comparison between the indices of the shadow economy for the developing countries under study. It is observed that the index of the shadow economy of Bahrain is $11 \%$, so it could be considered that it is the best according to other developing countries, followed by Oman and UAE, with a percentage of $17 \%$ and $18 \%$ respectively. Moreover, Jordan has the highest Index, as the shadow economy index is around $24 \%$.

\section{Conclusion}

After estimating the size of the shadow economy, the results reveal a significant relation between each of Total Tax/GDP, Intensity of Regulation, Corruption/Quality of public institutions, Unemployment Rate, Self-employment Rate, and Size of the Agricultural Sector, Fairness of Income Distribution and Entrepreneurial Ecosystem and Size of the Shadow Economy. Also, it had been found that there is a relation between the size of the shadow economy and labor force participation rate. Table 4 shows a summary of the research hypotheses results as per the above analysis conducted.

Table 4. Data analysis results summary.

\begin{tabular}{|c|c|c|}
\hline Hypothesis & Description & Results \\
\hline $\mathrm{H}_{1}$ & $\begin{array}{l}\text { There is a significant relation between Total Tax/GDP } \\
\text { and Size of Shadow Economy }\end{array}$ & Supported \\
\hline $\mathrm{H}_{2}$ & $\begin{array}{l}\text { There is a significant relation between Intensity of } \\
\text { Regulation and Size of Shadow Economy }\end{array}$ & Supported \\
\hline $\mathrm{H}_{3}$ & $\begin{array}{l}\text { There is a significant relation between Corruption/Quality } \\
\text { of public institutions and Size of Shadow Economy }\end{array}$ & Supported \\
\hline $\mathrm{H}_{4}$ & $\begin{array}{l}\text { There is a significant relation between Unemployment } \\
\text { Rate and Size of Shadow Economy }\end{array}$ & Supported \\
\hline $\mathrm{H}_{5}$ & $\begin{array}{l}\text { There is a significant relation between Self-employment } \\
\text { Rate and Size of Shadow Economy }\end{array}$ & Supported \\
\hline $\mathrm{H}_{6}$ & $\begin{array}{l}\text { There is a significant relation between Size of the } \\
\text { Agricultural Sector and Size of Shadow Economy }\end{array}$ & Supported \\
\hline $\mathrm{H}_{7}$ & $\begin{array}{l}\text { There is a significant relation between Fairness of Income } \\
\text { Distribution and Size of Shadow Economy }\end{array}$ & Supported \\
\hline $\mathrm{H}_{8}$ & $\begin{array}{l}\text { There is a significant relation between Entrepreneurial } \\
\text { Ecosystem and Size of Shadow Economy }\end{array}$ & Supported \\
\hline $\mathrm{H}_{9}$ & $\begin{array}{l}\text { There is a significant relation between Size of Shadow } \\
\text { Economy and Real GDP Growth Rate }\end{array}$ & Not Supported \\
\hline $\mathrm{H}_{10}$ & $\begin{array}{l}\text { There is a significant relation between Size of Shadow } \\
\text { Economy and Coins and Currency in Circulation }\end{array}$ & Not Supported \\
\hline $\mathrm{H}_{11}$ & $\begin{array}{l}\text { There is a significant relation between Size of Shadow } \\
\text { Economy and Labor Force Participation Rate }\end{array}$ & Supported \\
\hline $\mathrm{H}_{12}$ & $\begin{array}{l}\text { There is a significant relation between Size of Shadow } \\
\text { Economy and Inflation }\end{array}$ & Not Supported \\
\hline
\end{tabular}




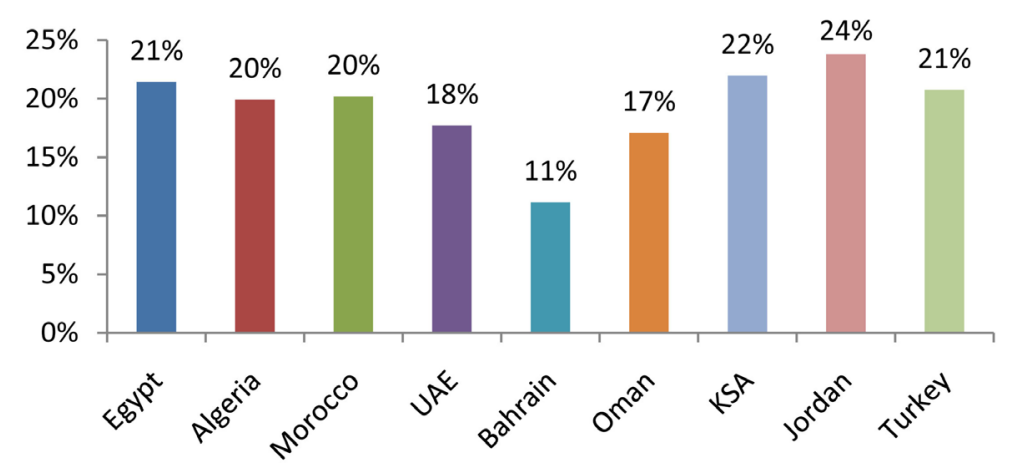

Figure 3. Indices of shadow economy size for nine developing countries using the MIMIC approach in the period 2000 to 2017. Source: Author's calculations.

\section{Conflicts of Interest}

The authors declare no conflicts of interest regarding the publication of this paper.

\section{References}

[1] Williams, C.C. and Schneider, F. (2016) Measuring the Global Shadow Economy: The Prevalence of Informal Work and Labour. Edward Elgar Publishing, Cheltenham.

[2] Duarte, P. (2017) The Relationship between GDP and the Size of the Informal Economy: Empirical Evidence for Spain. Empirical Economics, 52, 1409-1421. https://doi.org/10.1007/s00181-016-1109-1

[3] Duarte, P. (2017) The Relationship between GDP and the Size of the Informal Economy: Empirical Evidence for Spain. Empirical Economics, 52, 1409-1421. https://doi.org/10.1007/s00181-016-1109-1

[4] Putniņš, T.J. and Sauka, A. (2015) Measuring the Shadow Economy Using Company Managers. Journal of Comparative Economics, 43, 471-490. https://doi.org/10.1016/j.jce.2014.04.001

[5] Schneider, F. (2005) Shadow Economies around the World: What Do We Really Know? European Journal of Political Economy, 21, 598-642. https://doi.org/10.1016/j.ejpoleco.2004.10.002

[6] Schneider, F. and Enste, D. (2002) Hiding in the Shadows: The Growth of the Underground Economy (Vol. 30). International Monetary Fund, Washington DC.

[7] Tanzi, V. (1999) Uses and Abuses of Estimates of the Underground Economy. The Economic Journal, 109, 338-347. https://doi.org/10.1111/1468-0297.00437

[8] Feige, E.L. (2007) The Underground Economies: Tax Evasion and Information Distortion. Cambridge University Press, Cambridge.

[9] Jie, S.W., Tat, H.H., Rasli, A. and Chye, L.T. (2011) Underground Economy: Definition and Causes. Business and Management Review, 12, 14-24.

[10] Schneider, F. and Enste, D.H. (2000) Shadow Economies: Size, Causes, and Consequences. Journal of Economic Literature, 38, 77-114. https://doi.org/10.1257/jel.38.1.77

[11] Vo, D.H., Pham, T.M. and Authority, E.R. (2014) Any Link between Unofficial Economy and Official Economy? An Empirical Evidence from the ASEAN. International Journal of Economics and Finance, 6, 97. 
https://doi.org/10.5539/ijef.v6n11p97

[12] Hassan, M. and Schneider, F. (2016) Size and Development of the Shadow Economies of 157 Countries Worldwide: Updated and New Measures from 1999 to 2013.

[13] Schneider, F. and Bajada, C. (2003) The Size and Development of the Shadow Economies in the Asia-Pacific (No. 0301). Working Paper, Department of Economics, Johannes Kepler University of Linz, Linz.

[14] Schneider, F. (2010) The Influence of Public Institutions on the Shadow Economy: An Empirical Investigation for OECD Countries. Review of Law \& Economics, 6, 441-468. https://doi.org/10.2202/1555-5879.1542

[15] Buehn, A. and Schneider, F. (2012) Shadow Economies around the World: Novel Insights, Accepted Knowledge, and New Estimates. International Tax and Public Finance, 19, 139-171. https://doi.org/10.1007/s10797-011-9187-7

[16] Frey, B.S. and Pommerehne, W.W. (1984) The Hidden Economy: State and Prospects for Measurement 1. Review of Income and Wealth, 30, 1-23. https://doi.org/10.1111/j.1475-4991.1984.tb00474.x

[17] Thomas, J.J. (1992) Informal Economic Activity. Univ. of Michigan Pr, Michigan.

[18] Loayza, N.V. (1996) The Economics of Informal Sector: A Simple Model and Some Empirical Evidence from Latin America. Carnegie-Rochester Conference Series on Public Policy, 45, 129-162. https://doi.org/10.1016/S0167-2231(96)00021-8

[19] Pozo, S. (1996) Exploring the Underground Economy: Studies of Illegal and Unreported Activity. W.E. Upjohn Institute for Employment Research, Kalamazoo. https://doi.org/10.17848/9780880994279

[20] Lippert, O. and Walker, M. (1997) The Underground Economy: Global Evidence of Its Size and Impact. The Fraser Institute, Vancouver.

[21] Schneider, F. (1994) Can the Shadow Economy Be Reduced through Major Tax Reforms? An Empirical Investigation for Austria. Public Finance, 49, 137-152.

[22] Schneider, F. (1994) Measuring the Size and Development of the Shadow Economy. Can the Causes Be Found and the Obstacles Be Overcome? In: Essays on Economic Psychology, Springer, Berlin, Heidelberg, 193-212. https://doi.org/10.1007/978-3-642-48621-0 10

[23] Schneider, F. (1997) Empirical Results for the Size of the Shadow Economy of Western European Countries over Time.

[24] Schneider, F. (1998) Further Empirical Results of the Size of the Shadow Economy of 17 OECD-Countries over Time. 54th Congress of the IIPF Cordowa, Argentina and Discussion Paper, Linz.

[25] Schneider, F. (2003) The Development of the Shadow Economies and Shadow Labour Force of 21 OECD and 22 Transition Countries. CESifo DICE Report, 1, 17-23.

[26] Schneider, F. (2011) The Shadow Economy and Shadow Economy Labor Force: What Do We (Not) Know? https://doi.org/10.1515/9783110508222-011

[27] Johnson, S., Kaufman, D. and Shleifer, A. (1997) The Unofficial Economy in Transition. Brookings Papers on Economic Activity, 1997, 159-239. https://doi.org/10.2307/2534688

[28] Johnson, S., Kaufmann, D. and Zoido-Lobaton, P. (1998) Regulatory Discretion and the Unofficial Economy. The American Economic Review, 88, 387-392.

[29] Belev, B. (2003) The Informal Economy in the EU Accession Countries: Size, Scope, Trends and Challenges in the Process of EU Enlargement. 
[30] Gërxhani, K. (2003) Tax Evasion in Transition: Outcome of an Institutional Clash? Testing Feige's Conjecture in Albania. European Economic Review, 48, 729-745. https://doi.org/10.1016/j.euroecorev.2003.08.014

[31] Pedersen, S. (2003) The Shadow Economy in Germany, Great Britain and Scandinavia: A Measurement Based on Questionnaire Surveys (No. 10). Rockwool Foundation Research Unit, Copenhagen.

[32] Schneider, F. and Williams, C. (2013) The Shadow Economy. The Institute of Economic Affairs, London.

[33] Alma, J., Martinez-Vazquez, J. and Schneiderb, F. (2005) "Sizing" the Problem of the Hard-to-Tax. In: Taxing the Hard-to-Tax: Lessons from Theory and Practice, Emerald Group Publishing Limited, Bingley, 11-75.

https://doi.org/10.1016/S0573-8555(04)68802-X

[34] Dell'Anno, R. (2004) Estimating the Shadow Economy in Italy: A Structural Equation Approach (No. 2003-7).

[35] Dell'Anno, R. and Schneider, F.G. (2006) Estimating the Underground Economy by Using MIMIC Models: A Response to T. Breusch's Critique (No. 0607). Working Paper, Department of Economics, Johannes Kepler University of Linz, Linz.

[36] Feige, E.L. (1989) The Meaning and Measurement of the Underground Economy. In: Feige, E.L., Ed., The Underground Economies: Tax Evasion and Information Distortion, Cambridge University Press, Cambridge, 13-56. https://doi.org/10.1017/CBO9780511571749.003

[37] Thomas, J. (1999) Quantifying the Black Economy: Measurement without Theory Yet again? The Economic Journal, 109, 381-389. https://doi.org/10.1111/1468-0297.00441

[38] Fleming, M.H., Roman, J. and Farrel, G. (2000) The Informal Economy. Journal of International Affairs, 53, 387-409.

[39] Greenidge, K., Holder, C. and Mayers, S. (2009) Estimating the Size of the Informal Economy in Barbados. Journal of Business, Finance \& Economics in Emerging Economies, 4, 196-226.

[40] Feld, L.P. and Schneider, F. (2010) Survey on the Shadow Economy and Undeclared Earnings in OECD Countries. German Economic Review, 11, 109-149. https://doi.org/10.1111/j.1468-0475.2010.00509.x

[41] Sauka, A. and Schneider, F. (2016) Entrepreneurship and the Shadow Economy. Edward Elgar Publishing, Cheltenham. https://doi.org/10.4337/9781784719883

[42] Kirchgässner, G. (2017) On Estimating the Size of the Shadow Economy. German Economic Review, 18, 99-111. https://doi.org/10.1111/geer.12094

[43] Feld, L.P. and Schneider, F. (2017) Reply to Gebhard Kirchgässner. German Economic Review, 18, 112-117. https://doi.org/10.1111/geer.12097

[44] Schneider, F. (2000) The Increase of the Size of the Shadow Economy of 18 OECD Countries: Some Preliminary Explanations.

[45] Tedds, L.M. and Giles, D.E. (2002) Taxes and the Canadian Underground Economy. Taxes and the Canadian Underground Economy. Canadian Tax Foundation, Toronto.

[46] Giles, D.E., Tedds, L.M. and Werkneh, G. (2002) The Canadian Underground and Measured Economies: Granger Causality Results. Applied Economics, 34, 2347-2352. https://doi.org/10.1080/00036840210148021

[47] Giles, D.E. (1999) Measuring the Hidden Economy: Implications for Econometric Modelling. The Economic Journal, 109, 370-380. 
https://doi.org/10.1111/1468-0297.00440

[48] Dell'Anno, R., Gómez-Antonio, M. and Pardo, A. (2007) The Shadow Economy in Three Mediterranean Countries: France, Spain and Greece. A MIMIC Approach. Empirical Economics, 33, 51-84. https://doi.org/10.1007/s00181-006-0084-3

[49] Kucera, D. and Roncolato, L. (2008) Informal Employment: Two Contested Policy Issues. International Labour Review, 147, 321-348. https://doi.org/10.1111/j.1564-913X.2008.00039.x

[50] Dreher, A. and Schneider, F. (2010) Corruption and the Shadow Economy: An Empirical Analysis. Public Choice, 144, 215-238.

https://doi.org/10.1007/s11127-009-9513-0

[51] Dreher, A., Kotsogiannis, C. and McCorriston, S. (2009) How Do Institutions Affect Corruption and the Shadow Economy? International Tax and Public Finance, 16, 773. https://doi.org/10.1007/s10797-008-9089-5

[52] Schneider, F. and Teobaldelli, D. (2012) Beyond the Veil of Ignorance: The Influence of Direct Democracy on the Shadow Economy.

[53] Losby, J.L., Else, J.F., Kingslow, M.E., Edgcomb, E.L., Malm, E.T. and Kao, V. (2002) Informal Economy Literature Review. ISED Consulting and Research. 